\title{
Assessment of hydrological response in Subarnarekha river basin under anticipated climate change scenarios
}

\author{
Madhusudana Rao C. ${ }^{*}$, Bardhan A. ${ }^{2}$ and Patra J.P. ${ }^{3}$ \\ ${ }^{1}$ Department of Civil Engineering, National Institute of Technology Jamshedpur, Jamshedpur-831014, India \\ 2Department of Civil Engineering, National Institute of Technology Jamshedpur, Jamshedpur-831014, India \\ ${ }^{3}$ Surface Water Hydrology Division, National Institute of Hydrology, Roorkee, Roorkee- 247667, India \\ Received: 25/07/2019, Accepted: 02/06/2020, Available online: 10/06/2020 \\ *to whom all correspondence should be addressed: e-mail: madhu_chintalacheruvu@yahoo.co.in, cmrao.civil@nitjsr.ac.in \\ https://doi.org/10.30955/gnj.003191
}

Graphical abstract

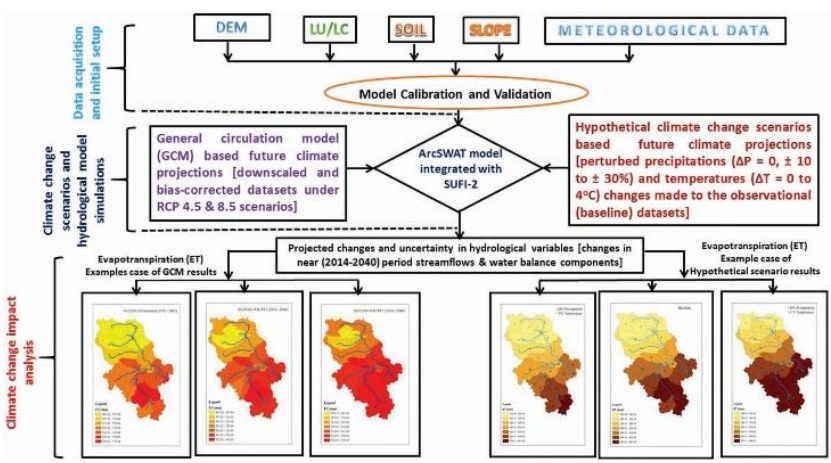

Abstract

Two hydrological climate modelling techniques, general circulation model (GCM) and hypothetical climate change scenarios, were used to analyse the hydrological response to the anticipated climate change scenarios in the Subarnarekha river basin in Eastern India. Both models verified individually for the same river basin and a comparative performance of the models was evaluated to relate the two models for the near (2014-2040) period climate. The hydrological response under the anticipated climate change in the Subarnarekha river basin is well assessed by GCM under the RCP 8.5 scenarios compared to the RCPs 4.5. Results indicate GCM best suited over the hypothetical climate change scenarios as GCM has demonstrated their potential in accurately reproducing the past observed climatic changes. The strong performance of the hypothetical climate change scenarios model, particularly for warming climate scenarios, suggests that it may have distinct advantages for the analysis of water balance components in the river basin. The monthly streamflows of Subarnarekha river basin was simulated using a total of 14 years (2000-2013) daily observed streamflow data in the ArCSWAT model integrated with model calibration and uncertainty analysis by means of SUFI-2 algorithm. The results indicate during the calibration the coefficient of determination $\left(R^{2}\right)$ and Nash-Sutcliff
Efficiency (NSE) were reported as 0.98 and 0.97 , respectively, while during the validation the $R^{2}$ and NSE were obtained as 0.94 and 0.94 , respectively, confirms the hydrological model performance was very good both in calibration and validation. The obtained climate change water impact index (Iccwı) values reveal the Subarnarekha river basin is more responsive to climate change. The reduction in precipitation along with the significant warming under the projected future climate is likely to reduce availability of water substantially in the study region. This work would be useful for the effective management of water resources for sustainable agriculture and in mitigating natural hazards such as droughts and floods in the study region.

Keywords: GCM, hypothetical climate change, ArcSWAT, SUFI-2, Subarnarekha river basin.

\section{Introduction}

Investigation of effects of climate change scenarios on water resources of river basins using climate models has received significant interest by the researchers. Climate models are the main source of information for assessing the potential impacts of climate change at global and regional scales and can be used for assessing future changes in streamflows of river basins.

Two widely used climate models for assessing the impacts of climate change on hydrological performance as implemented in a number of former studies are: 1) general circulation model (GCM) through statistical downscaling techniques (e.g., Wilby and Wigley, 1997; Hassan et al., 1998), 2) hypothetical climate change scenarios as input to hydrologic models (e.g., Nemec and Schaake, 1982; Gleick, 1986; Arnell, 1992; Ramadan et al., 2013; Uniyal et al., 2015). The GCM models through statistical downscaling approaches are considered the most reliable tools in studying climate change effects in the river basins (Goyal et al., 2012; Sachindra et al., 2014). The statistical downscaling relies on the empirical relationships derived between the GCM outputs (predictors of downscaling models) and the catchment scale hydro-climatic variables 
(predictands of downscaling models) such as precipitation, streamflow and evaporation (Hay and Clark, 2003).

However, there exist some discrepancy in the GCM approach i.e., GCM generate outputs at coarse grid scales in the order of a few hundred kilometres, their outputs cannot be directly used in catchment scale climate impact studies, which usually need hydro-climatic data at fine spatial resolutions (Sachindra et al., 2014). This discrepancy indicates the scale mismatch between the GCM outputs and the hydro-climatic information needed at the catchment level. This may be considered as the major setback of the GCM model approach, even when it evidenced as the most reliable tool in assessing the climate change effects in the river basins.

Therefore, considering the discrepancy in the GCM model approach the hypothetical climate change scenarios for the initial stage of climate impact studies is widely used. Many researchers (e.g., Clinton, 1994; Bobba et al., 1999; Mimikou et al., 2000; Xu, 2000; Baltas and Mimikou, 2007; Rehana and Mujumdar, 2011; Ramadan et al., 2013; Uniyal et al., 2015) have employed hypothetical climate change scenarios to perform the sensitivity analysis on river basins. Hypothetical scenarios are executed by perturbing the baseline simulation (the validated simulation forced with observed station data) as input (Mengistu and Sorteberg, 2012). The increase in temperature is considered according to IPCC (Climate Change, 2014). These hypothetical climate change scenarios are often used as an alternate model approaches to the GCMs as they can avoid the complex statistical downscaling procedure when applied for the river basin studies. However, the model selection is the process of choosing one of the models as the final model that addresses the river basin problem and performs better under the climate changing scenarios. Therefore, it is inevitable to carry a comparative performance evaluation study between the climate models to relate their advantages and disadvantages in the model approaches.

In this study, a comparative performance evaluation is proposed to relate the climate models i.e., GCM model and the hypothetical climate change scenarios for their appropriate use in the river basin studies. Knowing the advantages and disadvantages of these two model approaches, one can sensibly apply them for assessment of hydrological response in river basin studies.

Further, the SWAT (Soil and Water Assessment Tool, Arnold et al., 1998) model has been frequently used to carry out hydrologic modelling of river basins. The hydrological conditions are simulated to observe the climate change effect on water resources under the projected weather conditions in the river basins (Gosain et al., 2006). In order to simulate the streamflows of river basin the ArcSWAT (a physically-based, semi-distributed hydrologic model) integrated with model calibration and uncertainty analysis by means of Sequential Uncertainty Fitting (SUFI-2) algorithm is widely used by many researchers (e.g., Abbaspour et al., 2007; 2011; Gosain et al., 2006; Fiseha et al., 2014; Narsimlu et al., 2015; Uniyal et al., 2015; Mishra and Lilhare, 2016). The land use classification can easily be made in ArcSWAT model, whereas the SUFI-2 algorithm is used for model calibration, sensitivity and uncertainty analysis in streamflow prediction.

The Subarnarekha river basin in Eastern India needs effective management of water resources for sustainable agriculture and in mitigating natural hazards such as droughts and floods in the region. It is essential to assess the hydrological responses such as streamflows, water balance components, extreme flood events, variations in low flow across the basin under the anticipated climate change scenarios because this river basin is suffering from water shortage and natural hazards. Previous study focussed on annual streamflow assessment in this river basin together with the other river basins in India (Mishra and Lilhare, 2016). To the knowledge of the authors, no other notable work is seen in literature which focuses mainly on the comparative performance of the climate models used for assessment climate change effects for this river basin.

With this back ground, in the present study an effort is made to assess the climate change impact on hydrology of Subarnarekha river basin through the earlier described two climate model approaches such as GCM model and hypothetical climate change scenarios by setting two objectives (i) to calibrate and validate the ArcSWAT model for simulating monthly streamflows in the river basin, (ii) to evaluate the hydrological response to the anticipated climate changes in the river basin. This study provides support to water resource management for sustainable agriculture and in mitigating the natural flood and drought hazards in the river basin.

\section{Study area}

The Subarnarekha river basin is the smallest of the 14 major river basins in India and is passing through Jharkhand, West Bengal and Orissa states of Eastern India. The gauging station is located at a place called Ghatsila which is almost a peripheral boundary of Jharkhand state and is falling in the mid-reach of the river. The basin under consideration (Figure 1a) in the present study is up to Ghatsila gauging station in Jharkhand state, and is located between $21^{\circ} 33^{\prime}$ to $23^{\circ} 32^{\prime}$ North latitudes and $85^{\circ} 09^{\prime}$ to $87^{\circ} 27^{\prime}$ East longitudes in the North-East corner of the peninsular India. The total catchment area of the basin under consideration is about $14140 \mathrm{~km}^{2}$ with high topographical variations ranging from $49 \mathrm{~m}$ to $1049 \mathrm{~m}$ above mean sea level.

The Digital Elevation Model (DEM) of the basin is given in Figure $1 \mathrm{~b}$. The map of the land use classes of the basin is given in Figure 1c. Nine land use classess were found in the basin namely forest land, agricultural land, barren land, Indian grass land, water body, low density residential area, industrial area, mid-to-low density residential area and mid density residential area. The major area is covered by agricultural land (60.49\%), forest land (14.79\%), and Indian grass land (13.63\%) in the study region. 

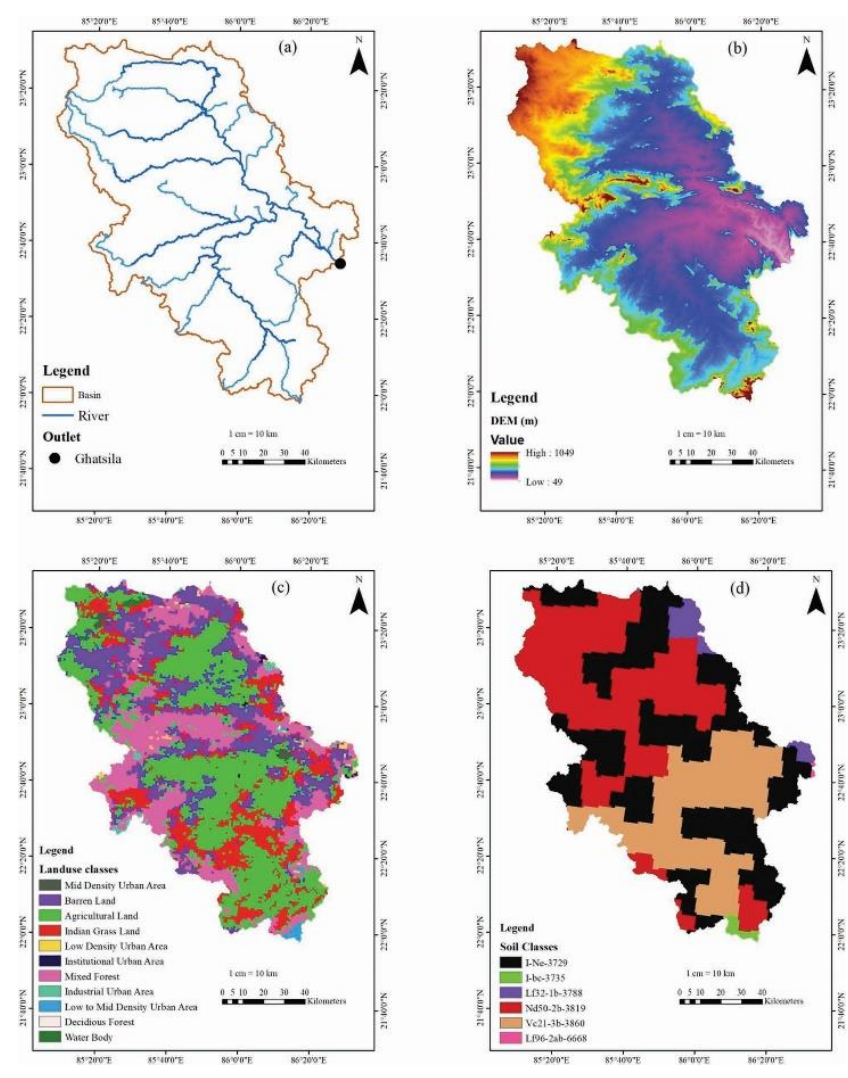

Figure 1. (a), (b), (c) and (d) Showing the location map with Ghatsila gauging station, Digital Elevation Model (DEM) map, land use class map and soil map of Subernarekha river basin, respectively

The present study uses the global soil data (Harmonized World Soil Data viewer-HWSD, version 1.2) from FAO (FAO, 2009). Figure $1 \mathrm{~d}$ show the six different soil class namely $1-$ Ne-3729, Nd50-2b-3819, Vc21-3b-3860, Lf32-1b-3788, Ibc-3735 and Lf96-2ab-6668. The major area is covered by I-Ne-3729 (37.31\%), Nd50-2b-3819 (34.71\%), Vc21-3b$3860(24.61 \%)$ in the river basin.

The river basin is generally influenced by the south-west monsoon, which begins in the month of June and extends up to October. According to Indian Meteorological Data (IMD), the average annual rainfall in the basin is about 1800 $\mathrm{mm}$. The Subarnarekha river is mostly a rainfed peninsular river. During the dry period, the river flow is almost no flow situation in the upper and middle reaches. The climate in the river basin is tropical with hot summer and mild winters. The mean monthly temperature varies from $40.5^{\circ} \mathrm{C}$ in the month of May to $9.00^{\circ} \mathrm{C}$ in the month of December. The annual average maximum and minimum temperatures vary from $32.40^{\circ} \mathrm{C}$ to $18.00^{\circ} \mathrm{C}$ in the study region. In recent years, the frequency of extreme climates has been increased in the study area. Consequently, the availability of surface water and groundwater has been reduced in the study region. Therefore, a comprehensive study is imperative to assess the impact of climate change on the hydrology of the Subarnarekha river basin.

\section{Data sources and methodology}

\subsection{Data sources}

The observed streamflow data at the Ghatsila gauging station for the period 2000-2013 (14 years) was obtained from central water commission (CWC), New Delhi, India. The major inputs, viz. digital elevation model (DEM) to represent the topography, Land use/land cover (LU/LC), soil maps to demonstrate the soil layers in the study region and hydro-meteorological data like daily rainfall in $\mathrm{mm}$, minimum and maximum daily temperature in ${ }^{\circ} \mathrm{C}$, relative humidity, solar radiation and wind speed are collected from different sources. Table 1 shows the summary of the different sources of major inputs i.e., spatial data with meteorological variables, grid resolutions and time periods.

\subsection{Methodology}

The present study evaluates the hydrological response to the anticipated climate change scenarios in the Subarnarekha river basin using two climate models: 1) general circulation model (GCM) datasets driven by biascorrected results of four different climate models under the representative concentration pathways (RCPs) 4.5 and 8.5 scenarios, 2) hypothetical climate change scenarios using the perturbed temperatures $\Delta \mathrm{T}=0$ to $4{ }^{\circ} \mathrm{C}$ with an interval of $0.5{ }^{\circ} \mathrm{C}$ and perturbed precipitations $\Delta \mathrm{P}=0$, $\pm 10, \pm 20$ and $\pm 30 \%$ as input to hydrologic model. These two model performances were verified individually on the same river basin. A comparative performance of the models was evaluated to relate the two models for the near (2014-2040) period climate.

The downscaled GCM and bias-corrected datasets and the hypothetical climate change scenarios have used as inputs to the ArcSWAT model for prediction of streamflows in the river basin. The ArcSWAT model was calibrated using SUFI2 optimization technique to evaluate the impact of climate change on streamflows and water balance components of Subarnarekha river basin up to Ghatsila gauging station. The ArcSWAT model was simulated for a period of 14 years, i.e., from 2000 to 2013. The first two years from 2000 to 2001 are considered as warmup period. The warmup period minimizes the effect of simulated initial state variables such as soil water content and surface residue. The next 8 years from 2002 to 2009 were considered as calibration period and the remaining 4 years from 2010 to 2013 were considered as validation period in the model.

Monthly calibration and validation were performed using the daily observed streamflow data of the Ghatsila gauging station in the Subarnarekha river basin. Further, the SCS (Soil Conservation Service) curve number method USDASCS (USDA, 1972) for estimating surface runoff, the Hargreaves method (Hargreaves et al., 1985) for estimation of evapotranspiration, the Muskingum-Cunge method (Cunge, 1969) for flow routing and the SUFI-2 algorithm for sensitivity and uncertainty analysis linked to SWAT-CUP (Abbaspour et al., 2007) were used in the study. 
Table 1. Summarized spatial data descriptions and their sources

\begin{tabular}{|c|c|c|c|c|}
\hline Sl. no. & Spatial data & Description/resolution & Duration/time period & Source \\
\hline 1. & Digital Elevation Model & $30 \mathrm{~m} \times 30 \mathrm{~m}$ grid resolution DEM to represent the topography & Collected on December 2015 & Shuttle Radar Topography Mission (SRTM) of USGS \\
\hline 2. & Land use and land cover & $\begin{array}{l}1 \mathrm{~km} \times 1 \mathrm{~km} \text { grid resolution LU/LC map to represent the crops and } \\
\text { urban specific digital layers }\end{array}$ & 2005 Map & $\begin{array}{l}\text { Nation Remote Sensing Centre, India/Water } \\
\text { Resources information System (http://www.india- } \\
\text { wris.nrsc.gov.in) and Texas A \& M University } \\
\text { (http://swat.tamu.edu/) }\end{array}$ \\
\hline 3. & Soil & $1 \mathrm{~km} \times 1 \mathrm{~km}$ grid resolution soil map to demonstrate the soil layer & 2009 FAO soil Map & Food and Agriculture Organization (FAO) \\
\hline 4. & Hydrological data & $\begin{array}{c}\text { Gauged daily discharge data at Ghatsila gauging station of } \\
\text { Subarnarekha river }\end{array}$ & $2000-2013$ & Central Water Commission (CWC), New Delhi, India \\
\hline 5. & $\begin{array}{l}\text { Weather inputs (for model } \\
\text { simulation) }\end{array}$ & $\begin{array}{c}0.25^{\circ} \times 0.25^{\circ} \text { grid resolution daily precipitation data and } 0.5^{\circ} \times 0.5^{\circ} \\
\text { grid resolution data of weather inputs such as maximum and } \\
\text { minimum temperature, relative humidity, solar radiation and wind } \\
\text { speed daily data }\end{array}$ & $2000-2013$ & $\begin{array}{l}\text { Indian Meteorological Department (IMD), Pune, } \\
\text { India }\end{array}$ \\
\hline 6. & Climate change data & $\begin{array}{l}0.5^{\circ} \times 0.5^{\circ} \text { grid resolution precipitation and temperature (maximum } \\
\text { and minimum) data on daily time step }\end{array}$ & $\begin{array}{l}\text { Historic (1976-2005) period and } \\
\text { Near (2014-2040) period }\end{array}$ & CORDEX-South Asia data set from IITM \\
\hline \multicolumn{2}{|c|}{ Institute } & Contributing modelling centre & & Resolution (degree) \\
\hline \multicolumn{2}{|c|}{ CSIRO } & CSIRO, Australia & S1-0 & CCAM-1391M \\
\hline \multicolumn{2}{|c|}{ CSIRO } & $\begin{array}{l}\text { nal de Recherches Météorologiques (CNRM), } \\
\text { France }\end{array}$ & CM5 & CCAM-1391M \\
\hline \multicolumn{2}{|c|}{ CSIRO } & MPI-M, Germany & $M-L R$ & CCAM-1391M \\
\hline \multicolumn{2}{|c|}{ CSIRO } & vegian Climate Centre (NCC), Norway & 11-M & CCAM-1391M \\
\hline
\end{tabular}

Note: CSIRO = Commonwealth Scientific and Industrial Research Organization; GCM = Global Climate Modal; RCM = Regional Climate Model, CCAM = Conformal-Cubic Atmospheric Model

Table 3. Summary of performance statistics showing the ArCSWAT model efficiency in estimating the streamflows for monthly time step both in calibration and validation periods

\begin{tabular}{|c|c|c|c|c|c|}
\hline \multirow{2}{*}{ Sl. no. } & \multirow{2}{*}{ Statistics } & \multirow{2}{*}{ Value } & \multicolumn{2}{|c|}{ Monthly time step } & \multirow{2}{*}{$\begin{array}{l}\text { Performance rating (adopted } \\
\text { from Moriasi et al., (2007) }\end{array}$} \\
\hline & & & Calibration period & Validation period & \\
\hline 1. & $R^{2}=\frac{\left[\sum\left(Q_{0, j}-\bar{Q}_{0}\right)\left(Q_{s, j}-\bar{Q}_{s}\right)^{2}\right.}{\sum\left(Q_{0, j}-\bar{Q}_{0}\right)^{2} \sum\left(Q_{s, j}-\bar{Q}_{s}\right)^{2}}$ & Closer the value of $R^{2}$ to 1 , the simulated and observed values are very close. & 0.98 & 0.94 & Very good \\
\hline 2. & $N S E=1-\frac{\sum_{i}\left(Q_{0}-Q_{s}\right)_{i}^{2}}{\sum_{i}\left(Q_{0, i}-\bar{Q}_{0}\right)^{2}}$ & Ranges between - $\infty$ to 1 , with optimal value of 1 . & 0.97 & 0.94 & Very good \\
\hline 3. & $P B \mid A S=100 \times \frac{\sum_{i=1}^{n}\left(Q_{o}-Q_{s}\right)_{i}}{\sum_{i=1}^{n} Q_{o, i}}$ & $\begin{array}{l}\text { Optimum value is zero, positive value indicates a tendency to underestimation and } \\
\text { negative value indicates a tendency to overestimation. }\end{array}$ & 7.30 & 3.50 & Very good for $< \pm 10$ \\
\hline 4. & $R S R=\frac{\sqrt{\sum_{i=1}^{n}\left(Q_{m}-Q_{s}\right)_{i}^{2}}}{\sqrt{\sum_{i=1}^{n}\left(Q_{m, i}-\overline{Q_{m}}\right)^{2}}}$ & $\begin{array}{l}\text { Value varies from } 0 \text { to positive value. The optimal value of RSR is } 0 \text { "which indicates best } \\
\text { model performance. The lower value RSR indicates the performance of the model is } \\
\text { better. }\end{array}$ & 0.17 & 0.25 & Very good \\
\hline
\end{tabular}




\subsection{1. $G C M$}

The GCM preferably embedded in so-called earth system models that account for variety of processes interactions in the climate systems. GCM produce their projections at relatively coarse spatial scales and they are unable to resolve sub-grid scale features such as topography, clouds and land use. The scale mismatch between the GCM outputs and the hydro-climatic information needed at the catchment level is a major obstacle in catchment climate impact assessment studies of hydrology and water resources (Willems and Vrac, 2011). Downscaling to the catchment scale can be accomplished through regional climate model (RCM) that uses the GCM as boundary conditions for the simulated regions.

In this study, four (ACCESS1-0, CNRM-CM5, MPI-ESM-LR, and NorESM1-M) historical (1976-2005) period and near (2014-2040) period simulated high-resolution GCM datasets for the representative concentration pathways (RCPs) 4.5 and 8.5 scenarios were used from high resolution Coordinated Regional Climate Downscaling Experiment (CORDEX)-South Asia of Indian Institute of Tropical Meteorology, Pune (IITM, 2016). The list of CORDEX South Asia Climate Projections used in the study is given in Table 2. The GCM datasets were downscaled through CORDEX, and taken them to a high-resolution of $0.5^{\circ} \times 0.5^{\circ}(\sim 50 \times 50 \mathrm{~km})$, with a bias-corrected performed through R- software.

\subsubsection{Hypothetical climate change scenarios}

Several researchers (e.g., Arnell et al., 1992; Clinton, 1994; $\mathrm{Xu}, 2000$; Jiang et al., 2007; Rehana and Mujumdar, 2011; Ramadan et al., 2013; Uniyal et al., 2015) have used hypothetical climate change scenarios for initial stage of climate change impact studies in river basins. These hypothetical scenarios can easily be generated to provide useful information on the response of hydrologic systems to plausible levels of climate change and variability (Clinton, 1994).

In the present study, these scenarios were performed by perturbing the baseline simulation (the validated simulation forced with observed station data) as input. A total of 63 (9 perturbed temperatures and 7 precipitations) anticipated hypothetical climate change scenarios such as combinations of temperature change $\Delta T=0$ to $4{ }^{\circ} \mathrm{C}$ with an interval of $0.5{ }^{\circ} \mathrm{C}$ (adding the prescribed change to the baseline simulation temperatures) and precipitation change $\Delta P=0, \pm 10, \pm 20$ and $\pm 30 \%$ (multiplied with a given factor) were considered in this study to assess the hydrologic response of the Subarnarekha river basin. But, other climatic variables such as relative humidity, wind speed, and solar radiation were considered to be unchanged (e.g., Mengistu and Sorteberg, 2012). Every scenario was then run for the same simulation period as the baseline simulation. The 12 year period from 2002 to 2013 is considered as baseline. Varied incremental climate scenarios are being applied to the daily temperatures and precipitation baseline datasets. The response of the Subarnarekha river basins streamflow and the water balance components under combinations of temperature and precipitation changes i.e., warming climate scenarios are examined.

\subsection{ArcSWAT model}

ArcSWAT is the most widely used watershed simulation model in geographic information system (GIS). In the present study, the ArcGIS10.2.2 interface for SWAT (ver. 2012) was used for water cycle simulation based on water balance. The water balance equation which governs the water balance components of SWAT model is given as:

$$
S W_{t}=S W_{0}+\sum_{i=1}^{t}\left(R_{d a y}-Q_{\text {surf }}-E_{a}-W_{\text {seep }}-Q_{g w}\right)
$$

where, $S W_{t}$ is the final soil water content $(\mathrm{mm}), S W_{0}$ is the initial soil water content on day $i(\mathrm{~mm}), t$ is the time (days), $R_{\text {day }}$ is the amount of precipitation on day $i(\mathrm{~mm}), Q_{\text {surf }}$ is the amount of surface runoff on day $i(\mathrm{~mm}), E_{a}$ is the amount of evapotranspiration on day $i(\mathrm{~mm}), W_{\text {seep }}$ is the amount of water entering the vadose zone from the soil profile on day $i(\mathrm{~mm}), Q_{g w}$ is the amount of return flow on day $i(\mathrm{~mm})$.

The ArcSWAT model calculates hydrological processes occurring in a watershed such as runoff, streamflow, sediment transport and nutrients transport at the hydrological response units (HRUs) level. The HRUs are unique blend of a specific soil type, land cover type and slope within a sub-basin. The study area consists of 21 subbasins which were divided into 251 HRUs that satisfactorily represent the watershed's heterogeneity. The present study did not employ any threshold refinement for HRU definition.

\subsection{SUFI-2 algorithm}

In this study, the SUFI-2 algorithm was used to investigate sensitivity and uncertainty in streamflow prediction. The SUFI-2 algorithm is based on Latin Hypercube Sampling (LHS) which is used to find the model output uncertainty by 95\% Probable Prediction Uncertainty (95PPU) evaluated at $2.5 \%$ and $97.5 \%$ levels of cumulative distribution of output variables (Abbaspour et al., 2007). The SUFI-2 starts with large parameter uncertainty so that the measured data should be within the 95PPU band. One-factor-At-a-time (OAT) sensitivity of LHS is used to select the sensitive parameters and its sensitiveness with its probable range like parameters value range should be higher or lower (Van Griensven, 2005). The SUFI-2 technique needs a minimum number of model simulations to attain a high-quality calibration and uncertainty results (Yang et al., 2008).

\subsection{Sensitivity analysis}

In this study, monthly calibration and validation was performed using daily observed streamflow data of the Ghatsila gauging station in Subarnarekha river basin. The Latin Hypercube One-factor-At-a-Time (LH-OAT) sensitivity analysis was used to identify the most sensitive input parameters. The ArcSWAT model was calibrated using SUFI-2 algorithm. The most likely sensitive SWAT parameters were included in the final calibration to perform the global sensitivity analysis for monthly time step. The most sensitive parameters were identified with respect to their sensitivity ranking done on the basis of 
t-stat value and $p$-value obtained at monthly time step for the study area.

The model performance during calibration and validation periods was evaluated by the use of selected performance statistics such as $\mathrm{R}^{2}$, NSE, PBIAS, RSR, p-factor and r-factor. Further, the parameters t-stat and $p$-value are also estimated for global sensitivity analysis. In order to know the effects of different climatic parameters on the streamflows and major water balance components of Subarnarekha river basin, the climate change sensitivity analysis is performed. The calibrated ArcSWAT model is used as the base platform for this purpose. The climate changing scenarios (perturbed temperatures and precipitations) have been used to perform the sensitivity analysis of major water balance components namely evapotranspiration, surface runoff, soil water, ground water contribution, percolation and water yield. The other weather components were not included in the present sensitivity analysis because of their less impact on major changes in climate (Mishra and Lilhare, 2016).

Further, the Iccwi (climate change water impact index) value is estimated to detect the degree of the temporal and spatial sensitivity of the basin. Iccwı be able to evaluate the sensitivity of any component of the water budget equation to all applied scenarios correctly (Ramadan et al., 2013). The Iccwivalue represents the state of the baseline and the streamflow response to climate change. The equation for Iccwi as proposed by Ramadan et al., 2013 is:

$$
I_{C C W I}=\sqrt{\frac{1}{m^{*} n} \sum_{i=1}^{m} \sum_{j=1}^{n}\left(\frac{U_{i . j}}{U_{b}} * 100-100\right)^{2}}
$$

where, $U_{i, j}$ is the streamflow for the $i^{t h}$ precipitation and $j^{\text {th }}$ temperature scenario, $U_{\mathrm{b}}$ is the streamflow baseline value, $m$ and $n$ are the total number of modelled precipitation and temperature scenarios, respectively. The value of Iccwi ranges from zero to positive value. The higher value of Iccw indicates the more sensitivity in the streamflow due to changes in precipitation and/or temperature.

\section{Results and discussion}

\subsection{Model calibration, validation and sensitivity analysis}

The hydrological model calibration and validation results were acceptable, when the performance statistics reach the desired limits between the observed and the final simulated data. The widely used performance statistics are $p$-factor, r-factor, coefficient of determination $\left(R^{2}\right)$, NashSutcliffe efficiency (NSE), percentage bias (PBIAS), and root mean square error to the standard deviation of measured data (RSR). The performance statistics value and the performance rating as adopted from Moriasi et al. (2007) is being followed by many researchers for systematic quantification of accuracy in the river basin simulations.

Table 3 demonstrates the summary of performance statistics of the ArcSWAT model efficiency in estimating the streamflows for monthly time step both in calibration and validation periods. For the results during the calibration period, the values of $\mathrm{R}^{2}$, NSE, PBIAS, and RSR obtained were $0.98,0.97,7.30$ and 0.17 , respectively, while during the validation the $\mathrm{R}^{2}$, NSE, PBIAS, and RSR obtained were 0.94 , $0.94,3.50$, and 0.25 , respectively, which indicates that the model performed very good for monthly time step both in calibration and validation periods.

Table 4. Sensitive SWAT parameters included in the final calibration, $t$-stat and $p$-values for monthly streamflow simulations

\begin{tabular}{|c|c|c|c|c|c|}
\hline Sl. no. & Parameter name & Parameters description & Rank & t-stat & p-value \\
\hline 1 & V_CH_K2.rte & $\begin{array}{l}\text { Effective hydraulic conductivity in main channel } \\
\text { alluvium ( } \mathrm{mm} / \mathrm{hr} \text { ) }\end{array}$ & 1 & -35.96 & 0.00 \\
\hline 2 & V_ALPHA_BF.gw & Baseflow alpha factor (days) & 2 & 35.44 & 0.00 \\
\hline 3 & $\mathrm{~V} \_\mathrm{CH} \_\mathrm{N} 2$.rte & Manning's " $n$ " value for the main channel & 3 & 8.40 & 0.00 \\
\hline 4 & R_SOL_AWC(..).sol & $\begin{array}{l}\text { Available water capacity of the soil layer soil layers } \\
\qquad(\mathrm{mm} / \mathrm{mm})\end{array}$ & 4 & -3.36 & 0.00 \\
\hline 5 & $\mathrm{R} \_\mathrm{CN} 2 . \mathrm{mgt}$ & SCS runoff curve number & 5 & 3.33 & 0.00 \\
\hline 6 & R_ESCO.hru & Soil evaporation compensation factor & 6 & -1.28 & 0.20 \\
\hline 7 & R_MSK_X.bsn & $\begin{array}{l}\text { Weighting factor controlling relative importance of } \\
\text { inflow rate and outflow rate in determining water } \\
\text { storage in reach segment }\end{array}$ & 7 & -1.15 & 0.25 \\
\hline 8 & R_GW_DELAY.gW & Groundwater delay (days) & 8 & -1.09 & 0.28 \\
\hline 9 & R_GWQMN.gW & Threshold depth of water in the shallow & 9 & -1.01 & 0.31 \\
\hline 10 & R_SOL_K(..).sol & Saturated hydraulic conductivity soil layers $(\mathrm{mm} / \mathrm{hr})$ & 10 & -0.92 & 0.36 \\
\hline 11 & R_MSK_CO2.bsn & $\begin{array}{l}\text { Calibration coefficient used to control impact of the } \\
\text { storage time constant for low flow }\end{array}$ & 11 & 0.85 & 0.40 \\
\hline 12 & V__SURLAG.bsn & Surface runoff lag time & 12 & 0.61 & 0.54 \\
\hline 13 & R_OV_N.hru & Manning's " $n$ " value for overland flow & 13 & -0.53 & 0.59 \\
\hline 14 & R_MSK_CO1.bsn & $\begin{array}{l}\text { Calibration coefficient used to control impact of the } \\
\text { storage time constant for normal flow }\end{array}$ & 14 & 0.03 & 0.97 \\
\hline
\end{tabular}

Further, the desired value for $\mathrm{p}$-factor, very close to 1 and the value of $r$-factor nearly to zero signifies excellent model performance with higher probability and lower uncertainty (Abbaspour et al., 2007; Uniyal et al., 2015). During the calibration period, the value for $p$-factor was 0.85 and the $r$-factor was 0.81 , and during the validation period they were obtained as 0.44 and 0.62 , respectively. It is revealed from the obtained $p$-factor value showing the model 
performance was very good. It also realized from the obtained $r$-value that the model was unable to capture the uncertainty exactly in the parameter estimates. The uncertainty may be due to discrepancy in the input rainfall as it was affected by climate change impacts in the study region. However, as the obtained PBIAS value is positive indicating that the model performance shows tendency to slightly underestimation.

The sensitive SWAT parameters included in the final calibration, t-stat and p-values for monthly streamflow simulations are presented in Table 4 . About 14 sensitive SWAT parameters (Table 4) were included in the final calibration to perform the global sensitivity analysis for monthly time step. Out of these 14 parameters, the first 5 parameters such as V__CH_K2.rte; V_ALPHA_BF.gw;

Table 5. Fitted values and the parameter range used for calibration
V_CH_N2.rte; R_SOL_AWC(..).sol; and R_CN2.mgt were identified as the most sensitive parameters with respect to their sensitivity ranking done on the $t$-stat values ranging from -35.96 to 3.33 and p-value shows zero in all 5 parameters assessed at monthly time step in the study area. The fitted value and the parameter range (minimum and maximum) for all the 14 sensitive parameters included in the final calibration are given in Table 5. The results of sensitivity analysis have confirmed that all these sensitive parameters are considered to be applicable to base flow, surface runoff, groundwater, channel routing, and soil properties. This final calibration model was used to assess the water balance components such as streamflows, evapotranspiration (ET), surface runoff (SURQ), groundwater contribution (GW_Q), percolation (PERC), water yield (WYLD) and soil water (SW) in the study area.

\begin{tabular}{|c|c|c|c|c|}
\hline \multirow{2}{*}{ SI. no. } & \multirow{2}{*}{ Parameter name } & \multirow{2}{*}{ Fitted value } & \multicolumn{2}{|c|}{ Parameter range } \\
\hline & & & Min value & Max value \\
\hline 1 & $\mathrm{~V} \_\mathrm{CH} \_\mathrm{K} 2$.rte & 21.84 & 0.01 & 38.17 \\
\hline 2 & V_ALPHA_BF.gw & 0.28 & -0.09 & 0.34 \\
\hline 3 & $\mathrm{~V} \_\mathrm{CH}$ _N2.rte & 0.12 & 0.01 & 0.13 \\
\hline 4 & R_SOL_AWC(..).sol & 0.45 & 0.17 & 0.54 \\
\hline 5 & $\mathrm{R} \_\mathrm{CN} 2 . \mathrm{mgt}$ & 0.01 & -0.02 & 0.04 \\
\hline 6 & R_ESCO.hru & -0.12 & -0.13 & -0.02 \\
\hline 7 & R_MSK_X.bsn & 0.34 & 0.12 & 0.41 \\
\hline 8 & R_GW_DELAY.gw & 0.06 & 0.01 & 0.21 \\
\hline 9 & R_GWQMN.gW & 0.05 & -0.20 & 0.21 \\
\hline 10 & R_SOL_K(..).sol & -0.13 & -0.13 & 0.02 \\
\hline 11 & R_MSK_CO2.bsn & 0.03 & -0.05 & 0.08 \\
\hline 12 & $\overline{\mathrm{V}}$ _SURLAG.bsn & 11.51 & 8.56 & 20.63 \\
\hline 13 & R_OV_N.hru & 0.20 & 0.11 & 0.35 \\
\hline 14 & R_MSK_CO1.bsn & -0.08 & -0.10 & 0.03 \\
\hline
\end{tabular}

\subsection{GCM model results}

\subsubsection{Projected changes and uncertainty in hydrologic variables}

The projected changes in the streamflows and water balance components of the Subarnarekha river basin were estimated for the near (2014-2040) period climate under the RCP 4.5 and 8.5 scenarios with reference to the historic (1976-2005) period. The near (2014-2040) period climate includes the recent past (2014-2020) period as the model simulation is ending in the year 2013 as per the available data. The staring year of the near period may be assumed immediately after the end of simulation period. This type of procedure is in practice (e.g. Mishra and Lilhare, 2016; Kumar et al., 2017). In order to meet the present and near period water requirements in the Subarnarekha river basin only near period climate changes were assessed and their results are demonstrated herein. The mid and end period climate changes were not presented in this study.

Table 6 shows the values of projected changes in the streamflow and water balance components with their percentage change in parenthesis computed using four GCM models under the RCPs 4.5 and 8.5 scenarios. Figures 2 depicts the pictorial views of projected changes in the water balance component ET of the Subarnarekha river basin for ACCESS1-0 historical and near period simulated GCM dataset under the RCPs 4.5 and 8.5 given as a sample case of the obtained results. Table 7 reveals the overall projected percentage change in the water balance components of Subarnarekha river basin computed using GCM model under the RCPs 4.5 and 8.5.

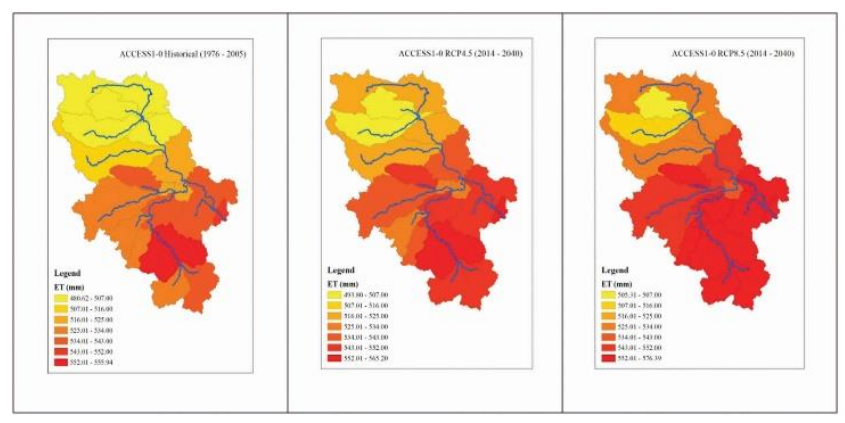

Figure 2. Depicts the pictorial views of projected changes in the water balance component ET of the Subarnarekha river basin for ACCESS1-0 historical and near period simulated GCM dataset under the RCPs 4.5 and 8.5 
Table 6. Showing the values of projected changes in the streamflow and water balance components with their percentage change in parenthesis computed using four GCM models under the RCPs 4.5 and 8.5 scenarios

\begin{tabular}{|c|c|c|}
\hline GCM model/water balance component & RCP4.5 & RCP8.5 \\
\hline \multicolumn{3}{|l|}{ Streamflow } \\
\hline ACCESS1-0 & $11.03(13.65)$ & $20.43(25.28)$ \\
\hline CNRM-CM5 & $-17.58(16.15)$ & $-18.49(16.98)$ \\
\hline MPI-ESM-LR & $-0.89(0.93)$ & $11.78(12.26)$ \\
\hline NorESM1-M & $5.83(6.36)$ & $12.64(13.79)$ \\
\hline \multicolumn{3}{|l|}{ ET } \\
\hline ACCESS1-0 & $13.11(2.55)$ & $26.20(5.10)$ \\
\hline CNRM-CM5 & $23.87(4.79)$ & $20.18(4.05)$ \\
\hline MPI-ESM-LR & $19.02(3.74)$ & $20.11(3.95)$ \\
\hline NorESM1-M & $14.00(2.74)$ & $19.65(3.84)$ \\
\hline \multicolumn{3}{|l|}{ SURQ } \\
\hline ACCESS1-0 & $15.23(11.08)$ & $39.97(29.07)$ \\
\hline CNRM-CM5 & $-21.40(12.12)$ & $-23.51(13.31)$ \\
\hline MPI-ESM-LR & $-14.46(8.70)$ & $12.21(7.35)$ \\
\hline NorESM1-M & $-0.57(0.36)$ & $19.33(12.33)$ \\
\hline \multicolumn{3}{|l|}{ GW_Q } \\
\hline ACCESS1-0 & $8.26(8.69)$ & $9.52(10.01)$ \\
\hline CNRM-CM5 & $-16.29(13.99)$ & $-15.00(12.89)$ \\
\hline MPI-ESM-LR & $12.32(12.33)$ & $18.92(18.94)$ \\
\hline NorESM1-M & $13.50(13.39)$ & $11.33(11.24)$ \\
\hline \multicolumn{3}{|l|}{ PERC } \\
\hline ACCESS1-0 & 8.67 (6.99) & $9.97(8.04)$ \\
\hline CNRM-CM5 & $-18.02(12.25)$ & $-15.39(10.46)$ \\
\hline MPI-ESM-LR & $12.75(9.88)$ & $20.05(15.54)$ \\
\hline NorESM1-M & $14.57(11.26)$ & $12.02(9.28)$ \\
\hline \multicolumn{3}{|l|}{ WYLD } \\
\hline ACCESS1-0 & $24.30(9.85)$ & $50.47(20.45)$ \\
\hline CNRM-CM5 & $-38.99(12.62)$ & $-39.65(12.83)$ \\
\hline MPI-ESM-LR & $-1.24(0.44)$ & $32.73(11.66)$ \\
\hline NorESM1-M & $14.08(5.17)$ & $31.71(11.64)$ \\
\hline \multicolumn{3}{|l|}{ SW } \\
\hline ACCESS1-0 & $-2.66(3.00)$ & $2.48(2.80)$ \\
\hline CNRM-CM5 & $-2.13(2.31)$ & $-1.36(1.47)$ \\
\hline MPI-ESM-LR & $0.34(0.37)$ & $0.01(0.01)$ \\
\hline NorESM1-M & $-3.32(3.62)$ & $-3.07(3.34)$ \\
\hline
\end{tabular}

Other than the CNRM-CM5 and MPI-ESM-LR models of GCM, the remaining two GCM model results show the increase in the streamflows of the Subarnarekha river basin in the near (2014-2040) period climate under the RCP 4.5 and 8.5 scenarios (Table 6). The CNRM-CM5 model shows decrease in streamflow at near period by an annual average of $16.15 \%$ and $16.98 \%$ (Table 6) under both RCP
4.5 and 8.5 scenarios, respectively. Whereas, MPI-ESM-LR model shows a decrease of $0.93 \%$ only in RCP 4.5 scenario but not in RCP 8.5 indicating that there is a larger intermodal uncertainty. Further, the overall streamflows is projected to increase by $0.73 \%$ and $8.59 \%$ (Table 7 ) in the Subarnarekha river basin in the near period climate under the RCP 4.5 and 8.5 scenarios, respectively.

Table 7. Overall projected percentage change in the water balance components of Subarnarekha river basin computed using GCM models under the RCPs 4.5 and 8.5

\begin{tabular}{ccc}
\hline Water balance components & RCP 4.5 & RCP 8.5 \\
\hline Streamflow & 0.73 & 8.59 \\
\hline ET & 3.46 & 4.24 \\
\hline SURQ & -2.53 & 8.86 \\
\hline GW_Q & 5.10 & 6.82 \\
\hline PERC & 3.97 & 5.60 \\
\hline WYD & 0.49 & 7.73 \\
\hline SW & -2.14 & -0.50 \\
\hline
\end{tabular}


The overall evapotranspiration (ET) is projected to increase by $3.46 \%$ and $4.24 \%$ under both RCP 4.5 and 8.5 scenarios, respectively for the near period (Table 7). The similar observation i.e., increase of ET is also seen in all the four GCM models (Table 6). The increase in ET can be attributed to significant increase in precipitation while a substantial rise in air temperature.

The surface runoff (SURQ) in the river basin is going to decrease by $2.53 \%$ under the RCP 4.5 scenario, whereas it is going to increase by $8.86 \%$ under the RCP 8.5 scenario (Table 7). Similarly, the other water balance components such as groundwater contribution (GW_Q), percolation (PERC), water yield (WYLD) shows increasing trend, whereas the soil water (SW) shows decreasing trend under the RCP 4.5 and 8.5 scenarios (Tables 6 and 7). The SW is projected to decrease by $2.14 \%$ and $0.50 \%$ under the RCP 4.5 and 8.5 scenarios. This indicate the initial and final soil water contents on monthly time steps are undergoing significant changes due to large variations in all other water balance components for near period climate change in the Table 8. Percentage change in streamflows

\begin{tabular}{cccccccccc}
\hline \multirow{2}{*}{$\mathbf{P} \%$} & $\mathbf{0}$ & $\mathbf{0}$ & $\mathbf{1}$ & $\mathbf{1 . 5}$ & $\mathbf{2}$ & $\mathbf{2 . 5}$ & $\mathbf{3}$ & $\mathbf{3} . \mathbf{5}$ & $\mathbf{4}$ \\
\cline { 2 - 10 } & $\mathbf{0}$ & $\mathbf{0 . 5}$ & -60.33 & -60.82 & -61.26 & -61.71 & -62.14 & -62.62 & -63.01 \\
\hline $\mathrm{p}-30 \%$ & -59.32 & -59.83 & -601 & -41 \\
\hline $\mathrm{p}-20 \%$ & -40.68 & -41.29 & -41.88 & -42.45 & -43.05 & -43.61 & -44.15 & -44.73 & -45.25 \\
\hline $\mathrm{p}-10 \%$ & -20.61 & -21.33 & -21.98 & -22.62 & -23.32 & -23.94 & -24.55 & -25.21 & -25.78 \\
\hline $\mathrm{p}$ & 0.00 & -0.76 & -1.47 & -2.14 & -2.87 & -3.56 & -4.25 & -4.96 & -5.57 \\
\hline $\mathrm{p}+10 \%$ & 21.33 & 20.53 & 19.80 & 19.09 & 18.32 & 17.61 & 16.89 & 16.14 & 15.52 \\
\hline $\mathrm{p}+20 \%$ & 42.85 & 42.06 & 41.30 & 40.55 & 39.75 & 39.05 & 38.29 & 37.51 & 36.85 \\
\hline $\mathrm{p}+30 \%$ & 65.18 & 64.33 & 63.58 & 62.79 & 61.98 & 61.21 & 60.44 & 59.61 & 58.91 \\
\hline
\end{tabular}

Figure $3 a$ and $3 b$ shows the pictorial views of subbasin wise spatial variations of water balance components of Subarnarekha river basin presented herein as the sample cases for the selected hypothetical climate change scenarios. Figure 3a demonstrates the sensitivity of water balance components ET, SURQ and GW_Q of Subarnarekha river basin under the impact of climate change by $1{ }^{\circ} \mathrm{C}$ in future with a variable rate of change in precipitation $(-10 \%$ and $+10 \%)$. Figure $3 b$ demonstrates the same as in the case of Figure 3a but for PERC, WYLD and SW of Subarnarekha river basin.

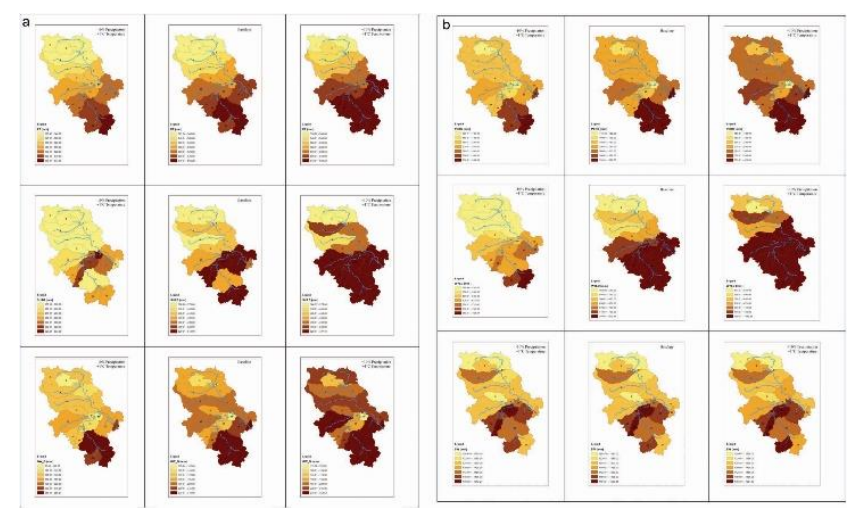

Figure 3. (a) Showing the pictorial views of sensitivity of water balance components ET, SURQ and GW_Q of Subarnarekha river basin under the impact of climate change by $1^{\circ} \mathrm{C}$ in future with a variable rate of change in precipitation $(-10 \%$ and $+10 \%)$. (b) Same as Figure $3 a$ but for the water balance components PERC, WYLD and SW river basin (Equation 1). It is observed from the GCM model results that the RCP 8.5 is more suitable than RCP 4.5 in assessing the hydrological response in the river basin for near period climate change scenarios as there is less intermodel uncertainty in the water balance component projections.

\subsection{Hypothetical scenarios model results}

Tables 8-14 demonstrates the percentage change in streamflows and water balance components such as ET, SURQ, GW_Q, PERC, WYLD, and SW, respectively, estimated on monthly time step under the considered hypothetical climate change scenarios. Note that in all the tables from Tables 8 to 14 , the alphabet $T$ denotes temperature in ${ }^{\circ} \mathrm{C}$ and $\mathrm{P}$ denotes percentage change of precipitation. The value zero given to $T$ and $P$ in the first column of all the tables indicates no change in precipitation and temperature. The positive/negative value indicates the percentage increase/reduction in precipitation.
The results of hypothetical sensitivity analysis show a warming of $4^{\circ} \mathrm{C}$ without any change in precipitation will lead to $5.57 \%$ reduction in streamflow in Subarnarekha river basin (Table 8). On the other hand, a 10, 20 and 30\% increase in precipitation under the projected future climate with a rise of $4^{\circ} \mathrm{C}$ or less will not cause any reduction streamflow in Subarnarekha river basin. However, reduction of $10,20,30 \%$ precipitation with $4^{\circ} \mathrm{C}$ warming will lead to reduction in streamflow by $25.78 \%, 45.25 \%$, and $63.01 \%$, respectively. Further, the reduction of $10 \%$ in precipitation without warm climate condition will lead to reduction in streamflow by $20.61 \%$ (Table 8 ). Therefore, from the results of hypothetical analysis it is revealed that the annual streamflows of Subarnarekha river basin are very sensitive to variations in precipitation changes and less sensitive to temperature changes in the river basin.

It is seen again from Table 9 and Figure $3 a$ that, evapotranspiration (ET) in the Subarnarekha river basin show less sensitivity as compared to other components. The warm climate condition of increase in temperature up to $4^{\circ} \mathrm{C}$ without any change in precipitation led to increase the ET by around $4.65 \%$. The reduction of $10 \%$ in precipitation without warm climate condition shows $2.04 \%$ decrease in ET; whereas considering the same condition of precipitation with warm climate of increase in temperature up to $4{ }^{\circ} \mathrm{C}$ show increase in ET by around $2.16 \%$. In all 7 different precipitation scenarios, with increase in temperature, the ET has increased. 
This happens due to proportionality of ET with temperature. Therefore, this analysis shows that any increase in precipitation along with climate warming will lead to increase in ET. On the other hand, a decrease in precipitation with climate warming in the basin will lead to reduction in ET in the Subarnarekha river basin.

Table 9. Percentage change in evapotranspiration (ET)

\begin{tabular}{cccccccccc}
\hline \multirow{2}{*}{$\mathbf{P} \%$} & $\mathbf{0}$ & $\mathbf{0 . 5}$ & $\mathbf{1}$ & $\mathbf{1 . 5}$ & $\mathbf{2}$ & $\mathbf{2 . 5}$ & $\mathbf{3}$ & $\mathbf{3 . 5}$ & $\mathbf{4}$ \\
\cline { 2 - 10 } & $\mathbf{0}$ & -7.92 & -7.20 & -6.95 & -6.52 & -6.13 & -5.55 & -5.00 & -4.55 \\
\hline $\mathrm{p}-30 \%$ & -8.44 & -4.68 & -4.16 & -3.52 & -2.50 & -2.45 & -2.08 & -1.40 & -0.97 \\
\hline $\mathrm{p}-20 \%$ & -5.03 & -1.78 & -1.23 & -0.66 & -0.05 & 0.50 & 1.10 & 1.54 & 2.16 \\
\hline $\mathrm{p}-10 \%$ & -2.04 & 0.63 & 1.49 & 1.71 & 2.34 & 2.92 & 3.49 & 4.13 & 4.65 \\
\hline $\mathrm{p}$ & 0.00 & 2.88 & 3.59 & 4.05 & 4.89 & 5.37 & 5.96 & 6.63 & 7.18 \\
\hline $\mathrm{p}+10 \%$ & 2.23 & 2.83 & 7.58 & 6.29 & 6.74 & 7.59 & 7.96 & 8.78 & 9.35 \\
\hline $\mathrm{p}+20 \%$ & 4.25 & 4.92 & 5.58 & 10.71 & 11.41 \\
\hline $\mathrm{p}+30 \%$ & 6.19 & 6.88 & 7.62 & 8.12 & 9.00 & 9.38 & 10.26 & & 10.71 \\
\hline
\end{tabular}

The surface runoff (SURQ) in the Subarnarekha river basin is high sensitive as compared to the other components after streamflow (Table 10, Figure 3a). In warm climate condition of increase in temperature up to $4{ }^{\circ} \mathrm{C}$ with $10 \%$ reduction in precipitation led to decrease in SURQ by $19.92 \%$; whereas with $10 \%$ increase in precipitation with warm climate condition of increase in temperature up to

Table 10. Percentage change in surface runoff (SURQ)

\begin{tabular}{cccccccccc}
\hline \multirow{2}{*}{$\mathbf{P} \%$} & $\mathbf{0}$ & $\mathbf{0 . 5}$ & $\mathbf{1}$ & $\mathbf{1 . 5}$ & $\mathbf{2}$ & $\mathbf{2 . 5}$ & $\mathbf{3}$ & $\mathbf{3 . 5}$ & $\mathbf{4}$ \\
\cline { 2 - 10 } & $\mathbf{0}$ & -51.11 & -51.41 & -51.53 & -51.71 & -51.87 & -52.13 & -52.36 & -52.57 \\
\hline $\mathrm{p}-30 \%$ & -50.90 & -51.57 & -36.68 & -36.89 \\
\hline $\mathrm{p}-20 \%$ & -34.00 & -35.27 & -35.50 & -35.76 & -36.21 & -36.23 & -36.40 & -19.65 & -19.92 \\
\hline $\mathrm{p}-10 \%$ & -15.69 & -18.18 & -18.43 & -18.68 & -18.95 & -19.19 & -19.46 & -1.83 & -2.07 \\
\hline $\mathrm{p}$ & 0.00 & -0.27 & -0.63 & -0.76 & -1.04 & -1.30 & -1.56 & -17 \\
\hline $\mathrm{p}+10 \%$ & 18.88 & 18.59 & 18.28 & 18.06 & 17.69 & 17.46 & 17.18 & 16.89 & 16.63 \\
\hline $\mathrm{p}+20 \%$ & 38.35 & 38.06 & 37.77 & 37.46 & 37.24 & 36.87 & 36.67 & 36.30 & 36.04 \\
\hline $\mathrm{p}+30 \%$ & 58.55 & 58.24 & 57.91 & 57.68 & 57.29 & 57.10 & 56.71 & 56.48 & 56.16 \\
\hline
\end{tabular}

The sensitivity results of groundwater contribution (GW_Q) are given in Table 11. In warm climate condition of increase in temperature up to $4{ }^{\circ} \mathrm{C}$ without any change in precipitation led to decrease of GW_Q by $9.34 \%$. With modest warm climatic conditions, increase in temperature increases up to $0.5{ }^{\circ} \mathrm{C}$ and $1{ }^{\circ} \mathrm{C}$ without any change in Table 11. Percentage change in ground water contribution (GW_Q)

\begin{tabular}{|c|c|c|c|c|c|c|c|c|c|}
\hline \multirow{2}{*}{ P\% } & \multicolumn{9}{|c|}{$\mathrm{T}^{\circ} \mathrm{C}$} \\
\hline & 0 & 0.5 & 1 & 1.5 & 2 & 2.5 & 3 & 3.5 & 4 \\
\hline p-30\% & -51.19 & -52.23 & -53.18 & -54.11 & -55.04 & -55.91 & -56.73 & -57.67 & -58.42 \\
\hline p-20\% & -33.10 & -34.53 & -35.59 & -36.67 & -38.74 & -38.75 & -39.68 & -40.76 & -41.64 \\
\hline p-10\% & -14.97 & -17.39 & -18.53 & -19.67 & -20.83 & -21.93 & -22.98 & -24.11 & -25.13 \\
\hline$p$ & 0.00 & -1.28 & -2.61 & -3.59 & -4.82 & -5.96 & -7.06 & -8.30 & -9.34 \\
\hline$p+10 \%$ & 15.43 & 14.13 & 12.85 & 11.75 & 10.36 & 9.29 & 8.16 & 6.89 & 5.81 \\
\hline$p+20 \%$ & 29.81 & 28.48 & 27.20 & 25.89 & 24.79 & 23.42 & 22.46 & 21.05 & 19.97 \\
\hline$p+30 \%$ & 43.74 & 42.38 & 41.02 & 39.91 & 38.40 & 37.46 & 36.03 & 34.96 & 33.74 \\
\hline
\end{tabular}

precipitation led to decrease in GW_Q by $1.28 \%$ and $2.61 \%$ respectively. This shows that the $\mathrm{GW}_{-} \mathrm{Q}$ is moderate sensitive to the climate change in the river basin. The ground water contributions in the Subarnarekha river basin are declining due to climate change. $4^{\circ} \mathrm{C}$, the surface runoff increased by $16.63 \%$ which indicates that the SURQ is highly sensitive even for modest change in precipitation. Similar to the streamflow a warming without any change in precipitation will cause a reduction in SURQ in the Subarnarekha river basin. On the other hand, a $30 \%$ increase/reduction in precipitation with $4^{\circ} \mathrm{C}$ warming will lead to an increase/decrease of $56.16 / 52.57 \%$ in SURQ.
The percentage change in percolation (PERC) values obtained for varied precipitations and temperatures scenarios are presented in Table 12 and their pictorial representations are demonstrated in Figure $3 \mathrm{~b}$. The PERC shows moderate sensitiveness with respect to hypothetical climate change scenarios in the Subarnarekha river basin.

As depicted in Table 13 and Figure $3 \mathrm{~b}$, the water yield (WYLD) show high sensitiveness with respect to hypothetical climate change scenarios in the Subarnarekha river basin. In case of warm climate condition of increase in temperature up to $4{ }^{\circ} \mathrm{C}$ without any change in precipitation led to a decrease of WYLD by around $4.41 \%$. Under modest warm climatic scenario like increase in temperature to $1{ }^{\circ} \mathrm{C}$ with an increase in precipitation up to $10 \%$ led to an increase of WYLD by $16.12 \%$; whereas for temperature increase up to $1{ }^{\circ} \mathrm{C}$ along with $10 \%$ reduction in 
precipitation led to a decrease of WYLD by $18.11 \%$ in the river basin.

Table 12. Percentage change in percolation (PERC)

\begin{tabular}{|c|c|c|c|c|c|c|c|c|c|}
\hline \multirow{2}{*}{ P\% } & \multicolumn{9}{|c|}{$\mathrm{T}^{\circ} \mathrm{C}$} \\
\hline & 0 & 0.5 & 1 & 1.5 & 2 & 2.5 & 3 & 3.5 & 4 \\
\hline$p-30 \%$ & -42.85 & -43.65 & -44.64 & -45.10 & -45.74 & -46.34 & -47.12 & -47.90 & -48.51 \\
\hline $\mathrm{p}-20 \%$ & -26.68 & -28.66 & -29.43 & -30.34 & -31.80 & -31.86 & -32.41 & -33.35 & -33.95 \\
\hline$p-10 \%$ & -11.33 & -14.36 & -15.18 & -16.01 & -16.85 & -17.64 & -18.45 & -19.14 & -19.96 \\
\hline$p$ & 0.00 & -0.94 & -2.13 & -2.54 & -3.44 & -4.25 & -5.03 & -5.95 & -6.67 \\
\hline$p+10 \%$ & 12.85 & 11.89 & 10.88 & 10.18 & 9.06 & 8.36 & 7.55 & 6.62 & 5.86 \\
\hline$p+20 \%$ & 24.83 & 23.84 & 22.87 & 21.86 & 21.19 & 20.05 & 19.50 & 18.41 & 17.64 \\
\hline$p+30 \%$ & 36.44 & 35.42 & 34.36 & 33.62 & 32.43 & 31.85 & 30.70 & 30.03 & 29.10 \\
\hline
\end{tabular}

Table 13. Percentage change in water yield (WYLD)

\begin{tabular}{cccccccccc}
\hline \multirow{2}{*}{$\mathbf{P} \%$} & $\mathbf{0}$ & $\mathbf{0 . 5}$ & $\mathbf{1}$ & $\mathbf{1 . 5}$ & $\mathbf{2}$ & $\mathbf{2 . 5}$ & $\mathbf{3}$ & $\mathbf{3}$ & $\mathbf{0}$ \\
\cline { 2 - 10 } & $\mathbf{0}$ & -5 & $\mathbf{4}$ & -53.23 & -53.62 \\
\hline $\mathrm{p}-30 \%$ & -50.14 & -50.62 & -51.13 & -51.51 & -51.94 & -52.33 & -52.77 & -53 \\
\hline $\mathrm{p}-20 \%$ & -33.07 & -34.39 & -34.89 & -35.42 & -36.39 & -36.40 & -36.82 & -37.37 & -37.79 \\
\hline $\mathrm{p}-10 \%$ & -15.14 & -17.57 & -18.11 & -18.65 & -19.21 & -19.72 & -20.24 & -20.74 & -21.25 \\
\hline $\mathrm{p}$ & 0.00 & -0.60 & -1.27 & -1.67 & -2.26 & -2.80 & -3.33 & -3.92 & -4.41 \\
\hline $\mathrm{p}+10 \%$ & 17.36 & 16.74 & 16.12 & 15.62 & 14.92 & 14.42 & 13.87 & 13.26 & 12.74 \\
\hline $\mathrm{p}+20 \%$ & 34.73 & 34.10 & 33.49 & 32.86 & 32.35 & 31.66 & 31.22 & 30.52 & 29.99 \\
\hline $\mathrm{p}+30 \%$ & 52.40 & 51.75 & 51.10 & 50.58 & 49.83 & 49.40 & 48.68 & 48.17 & 47.57 \\
\hline & & & & & & & & &
\end{tabular}

The Soil Water (SW) content shows unique behaviour compared to the other water balance components (Table 14, Figure 3b). This is expected due to the initial soil water $\left(\mathrm{SW}_{0}\right)$ and final soil water $\left(\mathrm{SW}_{\mathrm{t}}\right)$ contents available along with the other water balance components as mentioned in Equation (1) at a particular time step. In warm climate condition of increase in temperature up to
$4{ }^{\circ} \mathrm{C}$ without any change in precipitation led to a decrease of SW to around $2.14 \%$ and with $30 \%$ reduction in precipitation led to a decrease of soil water by around 7.15\%; whereas for $30 \%$ increase in precipitation along with an increase in temperature up to $4{ }^{\circ} \mathrm{C}$ led to an increase of soil water by around $0.35 \%$.

Table 14. Percentage change in soil water (SW)

\begin{tabular}{|c|c|c|c|c|c|c|c|c|c|}
\hline \multirow{2}{*}{ P\% } & \multicolumn{9}{|c|}{$\mathrm{T}^{\circ} \mathrm{C}$} \\
\hline & 0 & 0.5 & 1 & 1.5 & 2 & 2.5 & 3 & 3.5 & 4 \\
\hline$p-30 \%$ & -4.91 & -4.42 & -4.56 & -4.59 & -4.93 & -5.25 & -5.85 & -6.52 & -7.15 \\
\hline $\mathrm{p}-20 \%$ & -2.73 & -2.32 & -2.21 & -2.58 & -3.36 & -3.42 & -3.80 & -4.55 & -5.12 \\
\hline$p-10 \%$ & -1.09 & -0.75 & -0.62 & -0.90 & -1.32 & -1.71 & -2.29 & -2.76 & -3.48 \\
\hline$p$ & 0.00 & 0.46 & 0.34 & 0.36 & -0.04 & -0.40 & -0.92 & -1.53 & -2.14 \\
\hline$p+10 \%$ & 1.00 & 1.45 & 1.49 & 1.32 & 0.76 & 0.48 & -0.05 & -0.65 & -1.26 \\
\hline$p+20 \%$ & 1.85 & 2.28 & 2.37 & 2.02 & 1.79 & 1.21 & 0.90 & 0.20 & -0.42 \\
\hline$p+30 \%$ & 2.62 & 3.05 & 3.09 & 2.93 & 2.37 & 2.17 & 1.45 & 1.07 & 0.35 \\
\hline
\end{tabular}

Further, Table 15 demonstrates the Iccwı calculated for monthly streamflows for Subarnarekha river basin, and Table 16 demonstrates the Iccwı values obtained for water balance components and streamflows of Subarnarekha river basin. The results of Iccwı values revealed that the monthly streamflows and the water balance components of Subarnarekha river basin are more responsive to climate change as their Iccw values show higher values.

Table 15. Monthly $I_{c c w I}$ values for Subarnarekha river basin

\begin{tabular}{ccccccccccccc}
\hline Month & Jan & Feb & Mar & Apr & May & Jun & Jul & Aug & Sep & Oct & Nov & Dec \\
\hline $\mathrm{I}_{\mathrm{CCWI}}$ & 69.35 & 79.17 & 49.54 & 44.47 & 66.28 & 54.00 & 48.97 & 39.84 & 36.40 & 36.85 & 50.53 & 80.88 \\
\hline
\end{tabular}

Table 16. I IcWI values for water balance components and streamflow of Subarnarekha river basin

\begin{tabular}{cccccccc}
\hline Water Balance Components & WYLD & PERC & GW_Q & SURQ & ET & SW & Streamflow \\
\hline $\mathrm{I}_{\mathrm{CCW} I}$ & 34.07 & 26.65 & 32.00 & 36.46 & 5.60 & 2.81 & 41.29 \\
\hline
\end{tabular}




\section{Conclusions}

The ArcSWAT model was applied in the Subarnarekha river basin to simulate the monthly streamflows for the period 2000-2013 by following the calibration and validation analysis using the SUFI-2 algorithm. The outcomes of the sensitivity and uncertainty analysis using ArcSWAT and SUFI-2 indicate that the model is appropriate for streamflow prediction in the Subarnarekha river basin. The ArcSWAT model has closely simulated the observed streamflows in both the calibration and validation. This calibrated model can be used in further assessment of climate change using uncertainty techniques in the model calibration.

The hydrological response under the anticipated climate change in the Subarnarekha river basin is well assessed by GCM under the RCP 8.5 scenarios compared to the RCPs 4.5. Results indicate GCM model is best suitable over the hypothetical climate change scenarios as GCM has established their potential in accurately reproducing the past observed climatic changes. It can be seen from the GCM results that the monthly streamflows and the water balance components of Subarnarekha river basin are more responsive in the near (2014-2040) period climate. The mid and end period climate effects on the water resources of the river basin are under consideration in the future scope of this work.

The hypothetical climate change scenario model results show that the combined change in precipitation and temperature are likely to affect the streamflows of Subarnarekha river basin in addition to the decline of water availability in the river basin. The streamflows have tendency to be reduced with temperature increase and precipitation decrease. However, precipitation variation has a substantial weight on the river basin's streamflows behaviour. This may cause uncertainties in the future streamflows of the river basin. The Iccw values of the Subarnarekha river basin demonstrate more distinct sensitivity to climate change indicting that the monthly streamflows and the water balance components of the river basin are more responsive to climate change due to uncertainties and nonstationarity effects.

Therefore, it is suggested in future studies, to use the probabilistic analysis using probability density functions (PDFs) and cumulative distribution functions (CDFs) curves in quantifying the uncertainties in the future streamflows of the river basin. Further, the high and low flow statistics are to be assessed under nonstationarity assumptions as they are very important for flood estimation and drought determination in the river basin. This work would be useful for the effective management of soil and water resources for sustainable agriculture in the river basin.

\section{Acknowledgements}

The authors would like to express sincere gratitude to the editor and reviewers for their valuable and constructive comments which improved the quality of the present work.

\section{References}

Abbaspour K.C. (2011), SWAT Calibration and Uncertainty Programs: A User Manual, Swiss Federal Institute of Aquatic Science and Technology, Eawag, Dubendorf.

Abbaspour K.C., Vejdani M. and Haghighat S. (2007), SWAT-CUP: Calibration and uncertainty programs for SWAT. Proceedings of the International Congress on Modelling and Simulation (MODSIM 2007), Modelling and Simulation Society of Australia and New Zealand, New Zealand, 1596-1602.

Arnell N.W. (1992), Factors controlling the effects of climate change on river flow regimes in a humid temperate environment, Journal of Hydrology, 132, 321-342, doi: 10.1016/0022-1694(92)90184-W.

Arnold J.G., Srinivasan R., Muttiah R.S. and Williams J.R. (1998), Large area hydrologic modeling and assessment, Part I: Model development, JAWRA Journal of the American Water Resources Association, 34, 73-89.

Baltas E.A. and Mimikou M.A. (2007), Climate change impacts on the water supply of Thessaloniki, International Journal of Water Resources Development, 21(2), 341-353.

Bobba A.G., Jeffries D.S. and Singh V.P. (1999), Sensitivity of hydrological variables in the Northeast Pond River watershed, New found land, Canada, due to climate change, Water Resources Management, 13, 171-188.

Clinton M.R. (1994), Sensitivity of streamflow to climate change: A case study for Nebraska, Great Plains Research, 27-49.

Cunge J.A. (1969), On the subject of a flood propagation method (Muskingum Method), Journal of Hydraulic Research, IAHR, 7(2), 205-230. doi: 10.1080/00221686909500264.

FAO (2009), Harmonized World Soil Database (Version 1.1), In Global Environmental Change-Human and Policy Dimensions, FAO: Rome, Italy and IIASA, Laxenburg, Austria.

Fiseha B.M., Setegn S.G. and Melesse A.M. (2014), Impact of climate change on the hydrology of Upper Tiber river basin using bias corrected regional climate model, Water Resource Management, 28, 1327-1343.

Gleick P.H. (1986), Methods for evaluating the regional hydrologic impacts of global climatic changes, Journal of Hydrology, 88(1-2), 97-116.

Gosain A.K., Rao S. and Basuray D. (2006), Climate change impact assessment on hydrology of Indian river basins, Current Science, 90(3), 346-353.

Goyal M.K., Burn D.H. and Ojha C.S.P. (2012), Evaluation of machine learning tools as a statistical downscaling tool: temperatures projections for multi-stations for Thames River Basin, Canada, Theoretical and Applied Climatology, 108, 519-534, doi: 10.1007/s00704-011-0546-1.

Hargreaves G.L., Hargreaves G.H. and Riley J.P. (1985), Irrigation Water Requirements for Senegal River Basin, Journal of Irrigation and Drainage Engineering-ASCE, 111(3), 265-275. doi: 10.1061/(ASCE)0733-9437(1985)111:3(265).

Hassan H., Aramaki T., Hanaki K., Matsuo T. and Wilby R. (1998), Lake stratification and temperature profiles simulated using downscaled gcm output, Water Science and Technology, 38(11), 217-226.

Hay L.E. and Clark M.P. (2003), Use of statistically and dynamically downscaled atmospheric model output for hydrologic simulations in three mountainous basins in the western United States, Journal of Hydrology, 282, 56-75. 
IPCC (2014), Climate Change 2014: Synthesis Report. Contribution of Working Groups I, II and III to the Fifth Assessment Report of the Intergovernmental Panel on Climate Change [Core Writing Team R.K. Pachauri and L.A. Meyer (eds.)]. IPCC, Geneva, Switzerland, $151 \mathrm{pp}$.

Jiang T., Chen Y.D., Xu C.Y., Chen X., Chen X. and Singh V.P. (2007), Comparison of hydrological impacts of climate change simulated by six hydrological models in the Dongjiang Basin, South China, Journal of Hydrology, 336, 316-333, doi:10.1016/j.jhydrol.2007.01.010.

Kumar N., Tischbein B., Kusche J., Laux P., Beg M.K. and Bogardi J.J. (2017), Impact of climate change on water resources of upper Kharun catchment in Chhattisgarh, India, Journal of Hydrology: Regional Studies, 13, 189-207, doi: 10.1016/j.ejrh.2017.07.008.

Mengistu D.T. and Sorteberg A. (2012), Sensitivity of SWAT simulated streamflow to climate changes within the Eastern Nile River basin, Hydrology and Earth System Sciences, 16, 391-407, doi: 10.5194/hess-16-391-2012.

Mimikou M.A., Baltas E., Varanou E. and Pantazis K. (2000), Regional impacts of climate change on water resources quantity and quality indicators, Journal of Hydrology, 234, 95109.

Mishra V. and Lilhare R. (2016), Hydrologic sensitivity of Indian sub-continental river basins to climate change, Global and Planetary Change, doi: 10.1016/j.gloplacha.2016.01.003.

Moriasi D.N., Arnold J.G., Van Liew M.W., Bingner R.L., Harmel R.D. and Veith T.L. (2007), Model evaluation guidelines for systematic quantification of accuracy in watershed simulations, Transactions of the ASABE, 50(3), 885-900.

Narsimlu B., Gosain A.K., Chahar B.R., Singh S.K. and Srivastava P.K. (2015), SWAT Model Calibration and Uncertainty Analysis for Streamflow Prediction in the Kunwari River Basin, India, Using Sequential Uncertainty Fitting, Environmental Processes, 2, 79-95, DOI 10.1007/s40710-015-0064-8.

Nemec J. and Schaake J. (1982), Sensitivity of water resource systems to climate variation, Hydrological Sciences Journal, 27(3), 327-343, DOI: 10.1080/02626668209491113.

Ramadan H.H., Beighley R.E. and Ramamurthy A.S. (2013), Sensitivity analysis of climate change impact on the hydrology of the Litani Basin in Lebanon, International Journal of Environment and Pollution, 52(1/2), 65-81, doi: 10.1504/IJEP.2013.056359.

Rehana S. and Mujumdar P.P. (2011), River water quality response under hypothetical climate change scenarios in Tunga-Bhadrariver, India, Hydrological Processes, 25, 33733386, doi: 10.1002/hyp.8057.

Sachindra D.A., Huang F., Barton A., and Perera B.J.C. (2014). Statistical downscaling of general circulation model outputs to precipitation - part 1: calibration and validation, International Journal of Climatology, 34, 3264-3281 (2014), DOI: $10.1002 /$ joc.3914.

Uniyal B., Jha M.K. and Verma A.K. (2015), Assessing climate change impact on water balance components of a river basin using SWAT model, Water Resource Management, 29, 47674785, doi 10.1007/s11269-015-1089-5.

Uniyal B., Jha M.K. and Verma A.K. (2015), Parameter identification and uncertainty analysis for simulating streamflow in a river basin of eastern India, Hydrological Processes, 29(17), 3744-3766, doi: 10.1002/hyp.10446.
USDA-SCS (1972), USDA Soil Conservation Services National Engineering Handbook, Section 4: Hydrology, U.S. Government printing office, 1972.

Van Griensven A. (2005), Sensitivity, auto-calibration, uncertainty and model evaluation in SWAT 2005, UNESCO-IHE, 48.

Wilby R.L. and Wigley T.M.L. (1997), Downscaling general circulation model output: a review of methods and limitations, Progress in Physical Geography: Earth and Environment, 21(4), 530-548.

Willems P. and Vrac M. (2011), Statistical precipitation downscaling for small-scale hydrological impact investigations of climate change, Journal of Hydrology, 402(34), 193-205.

Xu C.Y. (2000), Modeling the effects of climate change on water resources in Central Sweden, Water Resources Management, 14, 177-189.

Yang J., Reichert P., Abbaspour K., Xia J. and Yang H. (2008) Comparing uncertainty analysis techniques for a SWAT application to the Chaohe Basin in China, Journal of Hydrology, 358, 1-23. 